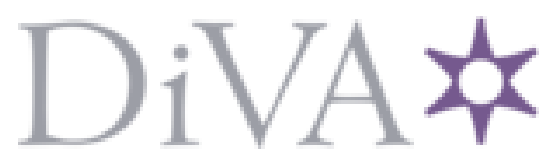

http://www.diva-portal.org

This is the published version of a chapter published in Contemporary approaches to activity theory: interdisciplinary perspectives on human behavior.

Citation for the original published chapter:

Popov, O. (2015)

Outdoor Science in Teacher Education.

In: Thomas Hansson (ed.), Contemporary approaches to activity theory: interdisciplinary perspectives on human behavior (pp. 128-142). hershey, pa: IGI Global https://doi.org/10.4018/978-1-4666-6603-0.ch008

N.B. When citing this work, cite the original published chapter.

This chapter/paper appears in Contemporary approaches to activity theory: interdisciplinary perspectives on human behavior edited by Thomas Hansson, Copyright 2006, IGI Global, www.igiglobal.com. Posted by permission of the publisher.

Permanent link to this version:

http://urn.kb.se/resolve?urn=urn:nbn:se:umu:diva-100087 


\section{Contemporary Approaches to Activity Theory:}

\section{Interdisciplinary Perspectives on Human Behavior}

Thomas Hansson

Blekinge Institute of Technology, School of Management (MAM), Sweden

A volume in the Advances in Human and Social

Aspects of Technology (AHSAT) Book Series 
Managing Director: Acquisitions Editor:

Production Editor:

Development Editor:

Typesetter:

Cover Design:
Lindsay Johnston

Kayla Wolfe

Christina Henning

Erin O'Dea

Cody Page

Jason Mull

Published in the United States of America by

Information Science Reference (an imprint of IGI Global)

701 E. Chocolate Avenue

Hershey PA, USA 17033

Tel: 717-533-8845

Fax: 717-533-8661

E-mail: cust@igi-global.com

Web site: http://www.igi-global.com

Copyright () 2015 by IGI Global. All rights reserved. No part of this publication may be reproduced, stored or distributed in any form or by any means, electronic or mechanical, including photocopying, without written permission from the publisher. Product or company names used in this set are for identification purposes only. Inclusion of the names of the products or companies does not indicate a claim of ownership by IGI Global of the trademark or registered trademark.

Library of Congress Cataloging-in-Publication Data

CIP Data

Library of Congress Cataloging-in-Publication Data

Contemporary approaches to activity theory : interdisciplinary perspectives on human behavior / Thomas Hansson, editor. pages $\mathrm{cm}$

Includes bibliographical references and index.

ISBN 978-1-4666-6603-0 (hardcover) -- ISBN 978-1-4666-6604-7 (ebook) -- ISBN 978-1-4666-6606-1 (print \& perpetual access) 1. Active learning. 2. Learning. 3. Learning, Psychology of. I. Hansson, Thomas.

LB1027.23.C66 2015

371.3--dc23

2014032307

This book is published in the IGI Global book series Advances in Human and Social Aspects of Technology (AHSAT) (ISSN: 2328-1316; eISSN: 2328-1324)

British Cataloguing in Publication Data

A Cataloguing in Publication record for this book is available from the British Library.

All work contributed to this book is new, previously-unpublished material. The views expressed in this book are those of the authors, but not necessarily of the publisher.

For electronic access to this publication, please contact: eresources@igi-global.com. 


\title{
Chapter 8 Outdoor Science in Teacher Education
}

\author{
Oleg Popov \\ Umeå University, Sweden
}

\begin{abstract}
This chapter is an account of the development of prospective teachers' competence to conduct outdoor science education. At the Department of Science and Mathematics Education, the students participate in outdoor education courses. They also plan, manage, and evaluate outdoor lessons designed as assignments in science education, participation in school practice, and summer courses. Many student teachers evaluate and analyse the pedagogical aspects of outdoor science when they carry out research projects in schools for their graduation thesis work. In order to understand the activity of science teaching and learning outdoors, a qualitative study was conducted. It was based on interviews with teacher educators and included studies of students' examination papers. A Cultural Historical Activity Theory (CHAT) lens was applied to the study. The theoretical framework helped to identify the prospective teachers' abilities and skills to design, implement, and evaluate tasks related to the professional competence of delivering outdoor science activities.
\end{abstract}

\section{INTRODUCTION}

Teaching and learning outdoors has a long educational history. Traditionally, the main forms of such outdoor activities are associated with fieldwork and outdoor educational visits, particularly in relation to the biological and geo-sciences (Dillon et al., 2006). The potential of natural settings and open air environments for science teaching has been actively explored by researchers and teacher educators around the world. For a review of the literature see Dillon et al. (2006) and

DOI: 10.4018/978-1-4666-6603-0.ch008
Tilling and Dillon (2007). Some educators have even expressed the conviction that "the future of school science lies outdoors" (Slingsby, 2006, p. 51). However, while there is a broad agreement that field studies are a laudable and form a necessary part of science education, Tilling and Dillon (2007) suggest that there is a decline in outdoor educational activities. Science studies in many schools and teacher education institutions are almost exclusively limited to indoor activities.

The situation can be partly explained by science teachers' low interest in organising outdoor lessons. This came as a consequence of their 
poorly developed pedagogical competence to conduct educational work outside the classroom. The situation is likely to become even worse if teacher education does not prepare prospective teachers for such work, as is often the case. Traditionally, science teachers are trained to teach in the classroom, in the computer room or in the laboratory. It is logical to assume that transfer of teaching from indoors to outdoors activities can be a problem. These issues need further investigation. What can be learned from teacher education institutions that systematically try to develop outdoor teaching competence?

In order for the reader to understand the findings presented in this chapter, we need to say some words about the current situation with regard to science teacher education. The situation at our university reflects the dynamics of the situation at national and global level. Over the last decade experienced science teacher educators have noticed a decrease in the preparedness, interest and motivation to study science by the students enrolling on the courses for prospective primary and secondary school teachers. This lack of interest has led to a reduction in the breadth and depth of content and methods of science given in teacher education. When students are offered elective courses in science they tend to avoid choosing them. However, outdoor education courses go against this trend. They still attract many applicants in spite of the heavy weight of science. The department has a long tradition of training prospective teachers in outdoor pedagogy. Outdoor studies are conducted in different forms and on different occasions, such as science course assignments, school practice, diploma work projects, activities with school children visiting the university campus, and on master degree courses. Usually, outdoor educational experiences receive very positive participant evaluations. Student teachers learn to recognize learning opportunities in the world around them. They learn to discover science as a means to explain natural phenomena while being in the natural environment.
Teachers' ability to teach constitutes the core of their professional competence. In this study we began by conceptualizing teacher competence. We used a definition developed by Döhrmann, Kaiser and Blömeke (2012) in a Teacher Education and Development Study in Mathematics (TEDS-M). Then we expanded on their project. They suggested that professional competence includes cognitive as well as affective-motivational aspects. Cognitive abilities are founded on a combination of subject knowledge and pedagogical knowledge. Affectivemotivational characteristics include professional beliefs, motivation and meta-cognitive abilities such as self-regulation. We felt that practical ability or embodied knowledge of practical outdoor experiences should be added to the classification offered by Döhrmann, et al. (2012) particularly for a description of science teachers' professional competence. In order to illustrate this contention, we would like to ask the reader to consider the case of boarding a canoe for a study trip on a lake. Motivation and theoretical knowledge are important, but the practical experience of keeping balance when stepping into the canoe will be decisive for initiating this activity without getting wet. Practical ability is usually meaningful and of course strongly context-bound.

This chapter aims to explore some aspects of prospective science teachers' professional competence that could with advantage be developed in an outdoor context. The role of context in science education is increasingly attracting the attention of researchers. This is reflected in recent academic publications (Lee, Wu, Tsai, 2013; Hansson, 2015). Nonetheless, the use of an outdoor context for training prospective science teachers remains an area with potential for further educational research and development of pedagogical practice.

Situated outdoor science teaching can be investigated with advantage through the theoretical lens of Cultural Historical Activity Theory (CHAT). This theoretical approach has been found to be productive since many outdoor educational projects deploy the principles and 
theoretical constructs of CHAT in the design, implementation and discussion of outdoor practices. The potential of CHAT for developing science education has recently been explored by several researchers (Giest \& Lompscher, 2003, Roth, Lee \& Hsu, 2009). Application of CHAT also helped us make some pedagogical deliberations about the particularities of teaching and learning in an outdoor context.

\section{THEORETICAL FRAMEWORK}

Cultural Historical Activity Theory is particularly concerned with the understanding of different kinds of human activity and the effects of proactively changing the context of activity in order to transform practice (Roth et al, 2009). In this study we focus on developing an understanding of how different aspects of prospective science teachers' competence could be constructed in an outdoor context. The importance of context operating as an active component of the learning process that interplays with learner's and teacher's activities was suggested by Vygotsky (1978). Following his line of thought, we focused on developing our understanding of how to study the laws and properties of nature in natural settings. Also, the context of active social interactions can strengthen prospective science teachers' professional competence. Undoubtedly, the main challenge of the teaching profession is to teach students how to learn, or in Cultural Historical Activity Theory terms, to organise productive learning activities in school.

According to Leont'ev (1981), the first and most fundamental form of human activity is external, practical, collaborative activity that is internalised later in human thought. Another fundamental claim of CHAT is that human activity can be understood only if we take into consideration the mediating artefacts (technical and cognitive tools) that mediate any activity (Leont'ev, 1981). In outdoor science teaching, investigation techniques or skills of scientific inquiry are artefacts of particular significance. They include observing, measuring, classifying, hypothesizing, etc. Important technical and cognitive tools are also different kinds of models.

CHAT suggests that the development of generic cognitive skills can be stimulated by properly organized learning activities. Kinard and Kozulin (2008, p. 25) say: "The learning activity includes orientation in the presented material, transformation of the presented material into a problem, planning the problem-solving process, reflection on chosen strategy and problem-solving means, as well as self-evaluation". When doing outdoor science, the content of learning is the acquisition of knowledge (embodied in learning objects) about properties and laws of nature. According to CHAT, the goals and motives of learning are considered the key components of learning activities. Leont'ev (1981) emphasised that the motive of learning determines the sense of the concrete learning activity. In general, learning activity is about learning to learn (Claxton, 2002) which is decisive in modern society (Friedman, 2007). In teacher education, the goal of learning activity is moreover about learning to teach, i.e. to develop teachers' professional competence. In our case, this ambition includes introducing student teachers to the experiences and intellectual challenges of outdoor learning and reflection on how to organise similar activities with their classes of students in the future.

As a unit of analysis in this study, we chose an activity oriented to developing prospective teachers' outdoor science education competence. We intend to develop the students' ability to conduct science studies in an outdoor context. Structurally, outdoor learning activities consist of goal oriented actions for solving particular tasks related to learning in an outdoor context. 


\section{METHODS}

A qualitative study was carried out at Umeå University in 2013. The data collection was organized through an analysis of ten students' research project reports carried out at the Department of Science and Mathematics Education. It also included semistructured interviews with five teacher educators. Convenience sampling was used in the selection of informants and data. Analysis of the student teachers' reports gave insight into the students' visions and the practice of the outdoor lesson designs. We learnt about the students' perceptions of the particularities of working in an outdoor educational context. All the student reports had been defended at the department over the last ten years. Our interviews focused on prospective teachers' learning and their learning to teach outdoors.

All of the teacher educators interviewed have been teaching outdoor courses for several years. They have also served as supervisors of the analyzed student teacher projects. The language of the interviews was Swedish. The interviews lasted from 45 to 60 minutes, they were tape-recorded and later some transcripts were translated into English. Validation of the interviews was carried out through follow-up discussions with the interviewees.

In the process of data analysis, the findings were thematically grouped and summarized. Quotations were used to exemplify the character of each group. In this way, categories of responses were generated. The results of the study are presented in a rather aggregated form with regard to sources of information, e.g. we avoid articulating which group of informants highlighted a particular theme. On the one hand this is done because students' projects are usually developed in tight collaboration with supervisors and therefore based on shared ideas. On the other hand, students often refer to and reflect on their own experiences of attending teacher education courses in their examination project reports.
The theoretical framework also contributed to the identification of themes during the process of data analysis. CHAT methodology highlights the role of contextual factors and mediating tools in the process of the realization of specific tasks. A review of current CHAT literature helped to achieve an understanding of the issues discussed in this chapter, such as empowerment of student teachers learning how to teach in complex and changing outdoor environment.

\section{LEARNING TO TEACH SCIENCE OUTDOORS}

We attempt to provide an analysis of findings concerning prospective teachers' learning to work with science outdoors. Different pedagogical considerations arose from the data collected in the light of a Cultural Historical Activity Theory perspective. Four headings relate to the conceptual issues of competence, context, learning activity and mediation.

\section{Expanding a Zone of Teacher Competence Construction}

Initial teacher education provides a variety of learning opportunities for construction of professional competence. An outdoor context could potentially be an optimal zone for learning, but unfortunately it is also a most challenging zone. Not only does new knowledge come true there, but previously acquired knowledge is also challenged by practical applications. Outdoor practical activities were reported to provide an opportunity for prospective teachers to make sense of their prior scientific knowledge acquired through formal and informal education.

In general, one of the fundamental features of teachers' professional competence is considered to be the ability to relate subject knowledge to knowledge associated with practical pedagogy. In order to clarify enhancement of students learning, 
Lucas (2007) with reference to Bernstein talks about this as a problem of "recontextualization". His outline suggests that decontextualized academic subject knowledge needs to be related to the context-bound experiential knowledge that learners bring to the scene. The latter includes what in science education is called everyday knowledge or learners' pre-conceptions. Issues related to methods for connecting theoretical (decontextualized) knowledge to practical (context-bound) knowledge in outdoor education was discussed in several student projects.

Furthermore, the interviewed teachereducators reflected on the decrease in space and time for laboratory practice available for prospective science teachers. There is a tendency for practical work in sciences to become infrequent and to be used mainly to illustrate previously leaned theories. The real nature of experiment as a source of scientific knowledge and provider of significant evidence about the veracity of scientific assumptions has become obscured. In that sense, science-directed practical activities outdoors can elucidate different aspects of the nature of science. Such perceptions are important to consider for a competent science teacher. This issue will be discussed in detail.

In the courses which contain an outdoor component, prospective teachers had the possibility to experience the learning potential that exists within and between contexts. They could learn to expand their pedagogical repertoire by contrasting and comparing contextual influences on their learning, development and competence. Teacher educators and colleagues in the study group possessed and exercised a broad collective expertise of acting in a variety of contexts. Students' reflections on the multiple pedagogical opportunities provided by varying contextual conditions allowed them to see the potential for expanding their professional competence. Here some features of teacher competence were related to contextual changes. It is a relevant question to ask how an outdoor context can help expand the teachers' zone of professional development.

\section{Contextual Influences}

Changing the educational context from indoors to outdoors activities can lead to new patterns of social relations among the students and between the teacher and the students. These affective changes were identified in many school projects. Learners could show new aspects of their personality during outdoor activities. Outdoor behaviours were in contrast to their usual behaviour shown in the classroom. These changes were rather complex and apparently they depended on many factors. It is worth mentioning that the outdoor context challenged the prospective teachers to learn to manage dynamic group relationships and gender roles in different age groups. They also became aware of the development of emotional, behavioural, social and other non-cognitive competencies, all of which are important for successful science education.

The entire pedagogical process is influenced by changes in the learning environment. Both categories of informants reflected on the importance for learners to develop the competences of seeing and foreseeing contextual influences. These are related, for example, to consideration of the structure and properties of context and the complexity of the phenomena embedded in it. The absence of 'walls and a roof' to frame learning changes the 'initial and boundary conditions' for solving the pedagogical tasks posed by the teacher. Different kinds of uncertainty characterise the open-air learning environment. We could distinguish reflection about the presence of fuzzy uncertainty as it appears in facts, assumptions and descriptions of natural objects or phenomena. We could also distinguish stochastic uncertainty as it appears in the occurrence of phenomena and their repeatability. Teacher educators and student teachers reported both of these as valid influences in/on an outdoor context. The teacher educators also mentioned effects of transferability - what is learned out of the classroom is easier to apply for the learners in an out-of-school context. 
Another important component of outdoor education competence could be called the ability to respond to the context. Students teachers learn to know themselves through the new context. They gain confidence to find, design and manage outdoors practical activities for different weather conditions. However, it takes time "for experience to reach the head", as one teacher educator formulated it, meaning such a basic thing as to learn to dress properly in order to avoid freezing, making routine controls of equipment in advance, etc. These routines are important aspects of building the prospective teachers' professional competence.

Outdoor science activities were reported to demand the use of cooperative learning. Many of them proved to be too complex to be dealt with individually. Collective activities in turn foster communication, group discussions and decisionmaking. The power of collaboration proves itself by empowering individual student learning. However, participation in collective activities allows for individual assessment demanded by the teacher education curriculum. Conducting individual monitoring of progress, diagnostics and final outdoor assessments was reported as a demanding task by the teacher educators. One way of carrying out individual assessment in the studied reports was to have certain students closely monitored throughout each session and to register the students' summative reflections at the end of each outdoor session.

Informants have also drawn our attention to other challenges in the outdoor context. Normally, people are used to being outdoors, mainly for recreation, sports and leisure. But they rarely go outdoors for learning. Therefore, they have to learn to learn outdoors. To a certain degree this also concerns the necessary schooling-in phase for prospective teachers when they start their outdoor courses. Placement of learning activities in a new context demands a new kind of orientation from the teachers. Learners have to learn to consider the outdoors as an educational environment.
Findings show that organization and structuring of outdoor teaching and learning demands implementation of rather advanced organisational and leadership skills. The informants also mentioned that in order to design outdoor science education activities, they would have to manage and coordinate interplay between narrow-local micro-, intermediate meso- and comprehensive global-macro levels of context:

- Learning environment, individual teacher, student group, actual space, time and tasks

- Institutional policy, leadership, curriculum and culture

- $\quad$ Supra-institutional, national socio-cultural and politico-economical frames.

The teacher educators and the student teachers in their rapports expressed concerns that educational authorities at meso- and macro-levels provide less active support for outdoor education than they did ten years ago. This support was more obvious in the previous curriculum for schools and teacher education. The student teachers' reports show that the local school context, traditions and culture strongly influence the organisation of outdoor science studies. They discourage or encourage the teachers' initiatives in conducting outdoor projects. The student teachers also reflected on the relationship between the local and global context. They raised concerns about the importance of knowing and using the social, cultural and historical dimensions of the local context and the necessity of critically connecting it to the global context, in particular if regarded from a scientific-ecological perspective.

\section{Identifying and Delimitating the Object of a Learning Activity}

The informants underlined that science content teaching outdoors is often a more pedagogically demanding job than is traditional indoors education. Natural phenomena and objects in real life 
contexts seldom provide obvious "hints" or explicit suggestions concerning what and how to study.

At least if compared with rather obvioustransparent support offered by a laboratory setting. Laboratory environment is designed for science exercises and provides many explicit and implicit suggestions about science principles that can be discovered and studied there. In contrast to indoor settings, clearinstructions and teacher guidance are often needed in the process of identifying learning objects (science content) outdoors. Studying science outdoors demands the consistent elimination of "noise" in the form of insignificant or disturbing features. What constitutes "noise" in any particular case? What should be taken out of consideration in order to build a model that helps to understand a phenomenon? In order to answer these questions learners need carefully designed "scaffolding" to assist the development of their scientific reasoning and Modeling skills.

Consider the case of a warm air balloon. Mechanical, thermal and chemical effects have very complex interplay there. Depending on the aim of study certain features become more important than others. So, the student teachers learn to "eliminate noise" from the complex reality of outdoors in order to formulate "solvable problems". They develop problem-construction competency by learning to build and study models of physical reality. Using CHAT terminology we can also say that they learn to identify the content of the learning activity.

Informants noted that planning the study of a phenomenon, such as resistance of air, could often be more difficult than planning measurement of an object, such as for example the weight of a stone. The task of selecting what property to measure is normally more explicit in the study of the object like a stone than it is in the study of a phenomenon like resistance of air. An appropriate model needs to be created to reflect the phenomenon being studied. To do so, the students have to be able to handle a variety of cognitive artefacts and Modelling tools. They also need to develop an ability to stay committed to solving a task for a longer period of time. The extended time span proved to be problematic for some students.

Prospective teachers have to be prepared to work with authentic problems that arise in everyday life. In the students' research projects (Sverin, 2011) several types of authentic problems were explored. There were tasks without a single right answer - open ended problems. There were tasks varying with changing environmental circumstances, for example depending on weather conditions. And there were tasks that demanded preliminary agreement about what is to be found out or measured. Sverin (2011, p. 52) found that at an initial phase of working with authentic tasks "the students had difficulties to formulate solvable problems, because they were used to working with closed, end-of-chapter problems with given answers. They did not perform any preparatory work at home to be able to identify and formulate solvable problems." Criteria for framing authentic problems were discussed before classes and lectures as well as a choice of criteria for identifying what accounts for an acceptable answer. Nevertheless, high school students needed close guidance when working with authentic tasks and elements of scientific inquiry in order to succeed.

It is relevant to highlight findings about making and overcoming mistakes. Usually, outdoor tasks allow several correct solutions. Outdoor tasks provide an opportunity to investigate and practice genuine scientific inquiry. The students learn to try out ideas, make mistakes and learn to accept that mistakes are a natural part of the learning process. Also included in the process is systematic reflection and self-evaluation. Probing plausible suggestions, eventually making mistakes and overcoming them, which are typical features of any scientific activity, become a natural part of learning that prospective teachers learn to deal with and value.

Student teachers had to learn to learn outdoors pedagogy and to develop competence to teach others to learn in an outdoor context. In most of 
the outdoor courses they practiced the design of school-oriented learning tasks. The tasks included leading their future students in different search directions, formulating "solvable" problems, finding out alternative solutions, discussing and choosing the most appropriate tasks for provoking deep discussions.

\section{New Tools and New Roles for the Tools That Mediate Learning}

People use a variety of mediating artefacts that shape the ways they think and act. They are physical instruments as well as symbolic and cognitive meaning-making tools. Regardless if taken together or individually they mediate investigations, reflective actions and communication. Glasgow, Cheyne and Yerrick (2010, p. 48) describe mediated processes of inquiry in science: "Scientists use their background knowledge of principles, concepts and theories, along with scientific process skills, to construct explanations for natural phenomena to allow them to understand the natural world." Mental and manipulative skills serve as important tools in the culture of understanding and advancing science. These are investigation techniques, science process skills and generic tools of scientific inquiry. This section of the chapter provides illustrations based on collected data, describing how physical and mental artefacts adapted for outdoors in science education could be used.

As a means to stimulate learning in their school projects, the student teachers used physical artefacts of large dimensions such as cable drums, cars and barrels. The saying that "size matters" proved to be legitimate starting point especially when learners have the possibility to explore physical phenomena outside their classroom walls. For example, for the study of torque in the physics course the following investigation with a sewing spool is usually suggested: "If the thread leaves the spool from the bottom of the axle when gently pulled, would the spool move forward or backward?" This experiment, when adapted to the outdoor environment using a rope and a large sized cable drum, gave an informative visual effect and provoked active discussions.

Disposable materials such as soft drink plastic bottles have been widely used as tools for science teaching around the world. Launching a waterrocket is probably one of the most popular science education activities conducted outdoors. The Internet and Google search engine offers millions of hits if you search "water rocket". Even primary school students can change different parameters prior to launching a rocket. They cover e.g. the proportion of water and air in the bottle. They have excellent opportunities to influence and observe plastic bottle rocket's flying capacity.

Several prospective teachers have reflected on and designed projects based on an experiential learning approach. They explore how outdoor learning can be assisted by direct bodily contact with surrounding natural objects. For example, feeling the force of air-resistance through an open car window gives first-hand experience and facilitates understanding of the physical properties of air. The human body itself becomes a tool of learning and remembering. People use different properties and parts of the human body for practical estimations and measurements. Historically, such knowledge has developed in different cultures when the need arose to know distances, compare and observe changes. However, human bodies as data collecting devices have limitations in a variety of ways. As an example, inaccuracies in measuring the speed of sound propagation, by seeing a flash and hearing the sound of a distant explosion, depend on individual reaction times. To gain personal experience of what it means to take exact measurements was found to be of great methodological value for the students.

As mentioned, science process skills such as measurements and estimations are important mediating artefacts of science learning activities. Conducting a measurement task outdoors can be more demanding than when it is conducted indoors. Consequently the studied informants 
elaborated extensively on this issue. Changes in environmental conditions like wind, humidity and sunshine influences the precision of measurements and make the reproducibility of experimental conditions and results far more problematic than if conducted in a corresponding laboratory setting. The outdoor context provides rich opportunity for reflection on precision, error and uncertainty in taking measurements. The importance of considering uncertainties becomes apparent and visible if conducted in such circumstances. Braund and Reiss (2006, p. 218) state that science out-ofclassroom provides the possibility to introduce the 'messiness of science' through authentic practical work. When different groups of students measure the same object using the same method or different methods and get varying results - there is an opportunity to discuss general principles of taking measurements in science.

Generic skills of estimations are very important in the practice of science. This was underlined by famous scientists like Richard Feynman (Gleick 1992). When conducting outdoor experiments students had to choose apparatus and measuring devices with an appropriate scale. Therefore, the need arises to plan and think ahead of time and estimate what values and magnitudes can be expected to be measured in an experiment. It is only then that the students will have an opportunity to note whether their choices and predictions corresponded to reality. They may also discuss the nature of any discrepancies noticed. So, taking measurements outdoors present practical and intellectual challenges to the students. Finding an attractive way to teach precision and errors in measurements has always been a challenge for science educators but work in outdoor settings provides an opportunity to analyze and discuss these issues.

Time to learn is an important pedagogical tool. Observations, experiments and investigations in an outdoor environment often demand a special kind of studies. This quality supplies a potential pedagogical advantage but also an administrative challenge. The teacher educators considered the extended time of students' engagement in learning activities as a positive factor -"learning takes time!" However, they also recognized potential difficulties in making the necessary class-schedule arrangements in schools that require administrative support.

\section{CONCLUSION}

Modern society demands citizens with the ability to learn how to learn (Claxton, 2002). According to Friedman (2007) this contention implies several mental operations and practical abilities.

... to constantly absorb, and teach yourself, new ways of doing old thing or new ways of doing new things. [...] it is not only what you know but how you learn that will set you apart. Because what you know today will be out-of-date sooner than you think. (p. 309)

From a CHAT perspective the need to learn-tolearn suggests that school systems, head teachers and teachers should focus on the systematic formation of learning activities that enable students to learn independently and efficiently (Giest \& Lompscher, 2003). The uncertainty and complexity of the context shaping science learning outdoors is of course a model of the real life uncertainties and complexities that students have to learn to deal with. The ability to adjust pedagogical actions to "fluid" learning contexts is an important feature of teachers' competence. In the same way that there cannot be a universal size of clothing for all children there is no universal teaching method that suits all learners all the time. It is however possible to consider the rationale of transferring science learning outdoors as a Modelling process that assist prospective teachers in their attempts at developing the ability to adjust their actions to a new or changing learning environment. Our findings show that learning activities outdoors 
provide rich and relevant experience corresponding to the demands of complex modern life with many in-built uncertainties. The OECD Core Competencies Framework defines personal attributes and skills enabling delivery of a role/job in a modern workplace. They develop in outdoor science education and they constitute an important part of teachers' professional competence:

- $\quad$ Flexible thinking involves the ability to adapt to a variety of situations, individuals or groups effectively.

- $\quad$ Analytical thinking is the ability to identify patterns between situations that are not obviously related and to identify key or underlying issues in complex situations.

- Drafting Skills is based on the ability to communicate respectfully ideas and often technical information in writing to ensure that information and messages are understood and have the desired impact.

- $\quad$ Teamwork and team leadership implies working cooperatively with others, be a part of a team, and assume the role of leader of a team.

- Achievement focus means generating results by assuming responsibility for one's performance and the correctness of one's interventions, recognising opportunities and acting efficiently, at the appropriate moment and within the given deadlines.

The student teachers' projects organised in schools covered the use of different mediating artefacts, investigative techniques, science process skills and generic tools of scientific inquiry. Such artefacts are important tools for managing outdoor science as well as for developing the learners' mental tools for future needs. The student teachers realized the important role played by the context in studying nature directly in natural settings. Their projects allowed for studying practical activities with a joint collaborative enactment of a shared goal.
Arguments about the importance of expanding science education to include outdoor settings always balanced the request for complementarity of indoor and outdoor teaching approaches. This combination allows discovery of different aspects of the students' learning potential and provides them with rich learning opportunities. Teaching science outdoors develops the learner's abilities to observe, ask, presume, verify and conduct a critical analysis of data. These skills of critical thinking are important in many professional activities, including student teachers' and teacher students' lessons. However, learners need guidance and collaboration in acquiring investigative techniques and critical thinking skills. The teacher can guide the students' work by suggesting learning tasks and monitoring the inquiry process based on their background and capabilities (Popov \& Tevel, 2007). The complexity of real world situations demands that the teacher takes on the role of a researcher and partner for the students rather than a possessor of the right answers.

The natural environment provides genuine opportunities for meaningful learning based on a combination of minds-on and hands-on activities, but it also requires additional preparation and carefully designed pre-, in- and post-field work to make outdoor learning activities productive. In Claxton's (2002, p. 29) words: "environments 'afford' resources, but these resources do not become functional aids to intelligent learning unless they are perceived as such by the learner." Kinard and Kozulin(2007) describe elements that constitute the core of learning activity: analysis of the task, planning of action, and reflection. They define reflection as a "trademark" of an approach focusing on development of learning to learn. The teacher educators of this study agreed with this, one of them saying: "Activity without reflection is meaningless, reflection without activity is empty. They should be in symbiosis. We always give feedback on students' reflections. This is a constitutive part of our profession." 
In summarizing the findings, one can add that outdoor activities can generate a feeling of empowerment in prospective science teachers, providing confidence and understanding of science processes when working in the expanded learning context. They develop the ability to use a broad range of mediating artefacts of learning and an open-minded approach to the study of natural objects and phenomena. Group work, team building, collective learning and the context of active social interactions proved to be a solid basis for outdoor education.

The primary distinguishing characteristic of the learning activity is that its main expected outcome is development of the subject of the activity - the learner. Outdoor science broadens learning opportunities and provides individual learning challenges for every student. Outdoor science also constitutes a zone for developing teacher professional competence. A teacher with the confidence to work in an outdoor context succeeds in organising meaningful science learning activities. This is a finding which lies in line with how CHAT conceives of a teacher. del Rio and Álvares (2002, p. 72) say s/he is an: "architect of meaning" who is capable of "bringing together physical and mental action, affectively as well as intellectually charged, and socially as well as instrumentally mediated". We hope that the pedagogical aspects of outdoor educational work presented in this chapter can lead to the further empirical and theoretical development of science teachers' professional competence.

\section{REFERENCES}

Braund, M., \& Reiss, M. (2006). Validity and worth in the science curriculum: Learning school science outside the laboratory. Curriculum Journal, 17(3), 213-228. doi:10.1080/09585170600909662
Claxton, G. (2002). Education for the learning age: a sociocultural approach to learning to learn. In G. Wells \& C. Claxton (Eds.), Learning for Life in the 21stCentury: Sociocultural Perspectives on the Future of Education. Blackwell Publishing.

Davydov, V. V. (1990). Types of Generalisation in Instruction. In Soviet studies in mathematics education (Vol. 2). Reston, VA: National Council of Teachers of Mathematics.

del Rio, P., \& Álvares, A. (2002). From activity to directivity: the question of involvement in education. In G. Wells \& C. Claxton (Eds.), Learning for Life in the 21st Century. Sociocultural Perspectives on the Future of Education (pp. 59-72). Oxford, UK: Blackwell Publishing. doi:10.1002/9780470753545.ch5

Dillon, J., Rickinson, M., Teamey, K., Morris, M., Choi, M. Y., Sanders, D., \& Benefield, P. (2006). The value of outdoor learning: Evidence from research in the UK and elsewhere. The School Science Review, 87(320), 107.

Döhrmann, M., Kaiser, G., \& Blömeke, S. (2012). The conceptualisation of mathematics competencies in the international teacher education study TEDS-M. ZDM Mathematics Education, 44(3), 325-340. doi:10.1007/s11858-012-0432-Z

Forsgren, T., \& Johansson, R. (2004). Fysikundervisning utomhus. (Unpublished undergraduate thesis). Umeå University, Umeå, Sweden.

Foster, S. (1989). Streetwise physics. The School Science Review, 70(254), 15-17.

Friedman, T. (2007). The World is Flat: A Brief History of the Twenty-first Century. New York, NY: Farrar, Straus and Giroux.

Giest, H., \& Lompscher, J. (2003). Formation of learning activity and theoretical thinking in science teaching. In A. Kozulin, B. Gindis, V. S. Ageyev, \& S. M. Miller (Eds.), Vygotsky's Educational Theory in Cultural Context. Cambridge, UK: Cambridge University Press. 
Glasgow, N. A., Cheyne, M., \& Yerrick, R. K. (2010). What Successful Science Teachers Do: 75 Research-Based Strategies. Thousand Oaks, CA: Corwin Press Inc.

Gleick, J. (1992). Genius: The Life and Science of Richard Feynman. New York, NY: Pantheon Books.

Hansson, T. (2014). Modeling and analyzing contextual influences. In T. Hansson (Ed.), Contemporary Approaches to Activity Theory: Interdisciplinary Perspectives on Human Behavior. Hershey, PA: IGI Global.

Kinard, J., \& Kozulin, A. (2008). Rigorous Mathematical Thinking: Conceptual Formation in the Mathematics Classroom. Cambridge, UK: Cambridge University Press. doi:10.1017/ CBO9780511814655

Lee, M.-H., Wu, Y.-T., \& Tsai, C.-C. (2013). Research trends in science education from 2003 to 2007: A content analysis of publications in selected journals. International Journal of Science Education, 31(15), 1999-2020. doi:10.1080/09500690802314876

Leont'ev, A. N. (1981). The problem of activity in psychology. In J.Wertsch (Ed.), The Concept of Activity in Soviet Psychology (pp. 7-71). New York, NY: M.E. Sharpe Inc.

Lucas, N. (2007). Rethinking initial teacher education for further education teachers: From standards-led to a knowledge-based approach. Teaching Education, 18(2), 93-106. doi:10.1080/10476210701325077

Markström, P., \& Cedergren, A. (2005). Praktisk fysik $i$ grundskolans tidigare år. (Unpublished undergraduate thesis). Umeå University, Umeå, Sweden.
Nilsson, P., Pendril, A.-M., \& Pettersson, H (2006). Learning physics with the body. In R. Janiuk \& E. Samonek-Miciuk (Eds.), Science and Technology Education of a Diverse World: Dilemmas, Needs and Partnerships. Lublin, Poland: Marie Curie-Sklodowska University Press.

OECD Competency Framework. (n.d.). Retrieved February 25, 2014, from http://www.oecd.org/ careers/oecd\%20level\%201_v1.pdf

Popov, O., \& Tevel, I. (2007). Developing prospective physics teachers' skill of independent experimental work using outdoors approach. Baltic Journal of Science Education, 6(1), 47-57.

Roth, W.-M., Lee, Y.-J., \& Hsu, P.-L. (2009). A tool for changing the world: Possibilities of culturalhistorical activity theory to reinvigorate science education. Studies in Science Education, 45(2), 131-167. doi:10.1080/03057260903142269

Slingsby. (2006). The future of school science lies outdoors. Journal of Biological Education, 40(2), 51-52.

Stetsenko, A. (2005). Activity as object-related: Resolving the dichotomy of individual and collective planes of activity. Mind, Culture, and Activity, 12(1),70-88. doi:10.1207/s15327884mca1201_6

Sverin, T. (2011). Open-ended problems in physics: Upper secondary technical program students' ways of approaching outdoor physics problems (Student research paper). Umeå Universitet.

Tilling, S., \& Dillon, J. (2007). Initial Teacher Education and the Outdoor Classroom: Standards for the Future: A Report on the Training of Pre-Service Teachers to Support the Development of Outdoor Teaching in Secondary Science Education. Field Studies Council. Association for Science Education.

Vygotsky, L. S. (1978). Mind and Society. Cambridge, MA: Harvard University Press. 


\section{ADDITIONAL READING}

Arievitch, I. M., \& Haenen, P. P. (2010). Connecting Sociocultural theory and educational practice: Galperin's approach. Educational Psychologist, 40(3),155-165.doi:10.1207/s15326985ep4003_2

Chaiklin, S., \& Hedegaard, M. (2013). Culturalhistorical Theory and Educational Practice: Some Radical-local Considerations. Nuances: estudos sobre Educação, Presidente Prudente, SP, v. 24, n. 1, p. 30-44, Retrieved June 6, 2014, from http:// revista.fct.unesp.br/index.php/Nuances/article/ viewFile/2151/chaiklin

Cole, M., \& Engeström, Y. (2007). Cultural-historical approaches to designing for development. J. Valsiner, A. Rosa (Eds.) The Cambridge Handbook of Sociocultural Psychology. Cambridge university press.

Davydov, V. V.(1999). What is real learning activity? M. Hedegaard, J. Lompscher, (Eds.). Learning Activity and Development. Aarhus, Denmark: Aarhus University Press, 123-138.

Davydov, V. V.(2008). Problems of Developmental Instruction: A Theoretical and Experimental Psychological Study. Hauppauge, NY: Nova Science. (Original work published 1986)

Engeström, Y., \& Miettinen, R. (1999). Activity Theory a well-kept secret. Y. Engeström, R. Miettinen \& R. L. Punamäki (Eds.). Perspectives on Activity Theory. (1-16). USA: Cambridge University Press.

Friedman, T. L. (2007). The World is Flat: A Brief History of the Twenty-frist Century. USA: Farrar, Straus and Giroux.

Garner, R. (1990). When children and adults do not use learning strategies: Towards a theory of settings. Review of Educational Research, 60(4), 517-529. doi:10.3102/00346543060004517
Hattie, J., Marsh, H. W., Neill, J. T., \& Richards, G. E. (1997). Adventure Education and Outward Bound: Out-of-class experiences that have a lasting effect. Review of Educational Research, 67(1), 43-87. doi:10.3102/00346543067001043

Kaptelinin, V., \& Nardi, B. A. (2006). Acting with Technology: Activity Theory and Interaction Design. USA: MIT Press.

Kozulin, A. (2003). Psychological tools and mediated learning. A. Kozulin, B. Gindis, V. S. Ageyev \& S. M. Miller (Eds.). Vygotsky's Educational Theory in Cultural Context (15-38). USA: Cambridge University Press.

Lompscher, J. (1999). Learning activity and its formation: ascending from the abstract to the concrete. M. Hedegaard, \& J. Lompscher, (Eds.). Learning Activity and Development. Aarhus, Denmark: Aarhus University Press, 139-166.

Martin, P. (2008). Teacher qualification guidelines, ecological literacy and outdoor education. Australian. Journal of Outdoor Education, 2(2), 32-38. http://www.latrobe.edu.au/education/ downloads/martin_p_Ecologicla-literacy-andOE.pdf Retrieved June 6, 2013

Minner, D. D., Levy, A. J., \& Century, J. (2010). Inquiry-based science instruction - what is it and does it matter? Results from a research synthesis years 1984 to 2002. Journal of Research in Science Teaching,47(4),474-496. doi:10.1002/tea.20347

Neill, J. T. (2008). Enhancing Life Effectiveness: The Impacts of Outdoor Education Programs. University of Western Sydney. Retrieved from 06/06/2013 http://www.ervaringsleren-nederland.nl/documents/experiental\%20learning $\% 20$ NEILL\%202008.pdf 
Peck, C. A., Gallucci, C., Sloan, T., \& Lippincott, A. (2009). Organizational learning and program renewal in teaching education: A socio-cultural theory of learning, innovation and change. Educational Research Review, 4(1), 16-25. doi:10.1016/j.edurev.2008.06.001

Popov, O. (2006). Developing outdoor activities and a website as resources to stimulate learning physics in teacher education. Journal of Physics Teacher Education Online, 3(3), 18-24.

Popov, O., \& Engh, R. (2013). Exploring pedagogical potential of outdoor context in teaching physics for prospective primary and secondary school teachers. Paper presented at International Conference of the Outdoor Learning Environment. 3-8 February 2013, Weizmann Institute of Science, Israel.

Steele, A. (2011). Beyond contradiction: Exploring the work of secondary science teachers as they embed environmental education in curricula. International Journal of Environmental and Science Education, 6(1), 1-22.

Stetsenko, A., \& Arievitch, I. M. (2004). The self in Cultural-Historical Activity Theory: Reclaiming the Unity of social and individual dimensions of human development. Theory \& Psychology, 14(4),475-503. doi:10.1177/0959354304044921

Talyzina, N. F. (1988). The modern state of the activity theory of learning. M. Hildebrand-Nilshon $\&$ G. Ruckriem. (Eds.) Proceedings of the 1st International Congress on Activity Theory. Berlin, 1986, 1, 219 - 227.

van Parreren, C. (1986). Development through instruction. E. Bol, J.P.P. Haenen \& M.A. Wolters (Eds.). Education for Cognitive Development. Proceedings of the Third International Symposium of Activity Theory. Den Haag: SVO/SOO, 38 -46.
Wells, G. (2003). Inquiry as an orientation for learning, teaching and teacher education. G. Wells \& C. Claxton (Eds.). Learning for Life in the 21st Century. Sociocultural Perspectives on the Future of Education. Blackwell Publishing. Oxford. 197-210.

Wertsch, J. V. (1991). Voices of the Mind. A Sociocultural Approach to Mediated Action. Cambridge, Massachusetts: Harvard University Press.

Zuckerman, G. (2004). Development of reflection through learning activity. European Journal of Psychology of Education, 19(1), 9-18. doi:10.1007/BF03173234

\section{KEY TERMS AND DEFINITIONS}

Competence: The ability of a person to reach specific achievements in order to be considered successful in the corresponding community of practice. It consists of cognitive, interactive, affective and practical capabilities and also attitudes and values, which are required for carrying out tasks and solving problems.

Cultural Historical Activity Theory: A theory of human development that sees human societies and their individual members as mutually constitutive. Personal development is shaped by the process of enculturation and individuals' thoughts and deeds serve to maintain or to alter the cultural milieu. At the heart of CHAT is therefore a tension between education as enculturation and education for autonomy and originality.

Learning Activity: An activity that has learning as a goal and also attached to the concept is an expected outcome. Learning activity involves transformation of the material by learners. The concept implies that new knowledge develops, involving appropriation of generalised ways of acting. 
Mediating Artefacts: The tools that people use and that shape the ways they think and act. These could be physical objects as well as symbolic and cognitive meaning-making tools that mediate communication and reflective actions.

Outdoor Context: Out-of-classroom open-air environments where natural and social dimensions are intertwined.
Outdoor Science Education Competence: An expression of the ability to teach and facilitate science learning in an outdoor context. Valued by different educational actors, experience of practical outdoor activities is essential in this respect.

Prospective Teachers: Are student teachers enrolled in a teacher education program for primary and secondary school. 